\title{
Effect of eccentric training on mitochondrial function and oxidative stress in the skeletal muscle of rats
}

\author{
L.A. Silva ${ }^{1}$, K.F. Bom ${ }^{1}$, C.B. Tromm ${ }^{1}$, G.L. Rosa ${ }^{1}$, I. Mariano ${ }^{1}$, B.G. Pozzi ${ }^{1}$, T. Tuon ${ }^{1}$ \\ E.L. Stresck ${ }^{2}$, C.T. Souza ${ }^{1}$ and R.A. Pinho ${ }^{1}$ \\ ${ }^{1}$ Laboratório de Fisiologia e Bioquímica do Exercício, Programa de Pós-Graduação em Ciências da Saúde, \\ Universidade do Extremo Sul Catarinense, Criciúma, SC, Brasil \\ ${ }^{2}$ Laboratório de Patofisiologia Experimental, Programa de Pós-Graduação em Ciências da Saúde, \\ Universidade do Extremo Sul Catarinense, Criciúma, SC, Brasil
}

\begin{abstract}
The objective of the present study was to investigate the effects of eccentric training on the activity of mitochondrial respiratory chain enzymes, oxidative stress, muscle damage, and inflammation of skeletal muscle. Eighteen male mice (CF1) weighing $30-35$ g were randomly divided into 3 groups $(\mathrm{N}=6)$ : untrained, trained eccentric running $\left(16^{\circ} ;\right.$ TER), and trained running $\left(0^{\circ}\right)$ (TR), and were submitted to an 8-week training program. TER increased muscle oxidative capacity (succinate dehydrogenase and complexes I and II) in a manner similar to TR, and TER did not decrease oxidative damage (xylenol and creatine phosphate) but increased antioxidant enzyme activity (superoxide dismutase and catalase) similar to TR. Muscle damage (creatine kinase) and inflammation (myeloperoxidase) were not reduced by TER. In conclusion, we suggest that TER improves mitochondrial function but does not reduce oxidative stress, muscle damage, or inflammation induced by eccentric contractions.
\end{abstract}

Key words: Eccentric training; Mitochondrial enzyme activity; Oxidative stress; Muscle damage; Inflammation

\section{Introduction}

The production of reactive oxygen species (ROS) during physical training depends on the type, intensity, and duration of exercise (1). Although regular exercise training is associated with numerous health benefits, it can be viewed as an intense physical stressor leading to increased oxidative cellular damage, likely due to the enhanced production of ROS (2). It appears that ROSmediated oxidation of proteins, lipids, and nucleic acids is not solely dependent on oxygen flux through the mitochondria, since oxygen uptake has been shown to differ drastically between exercise modes. Rather, multiple factors, including xanthine oxidase, disruption of ironcontaining proteins, calcium imbalance secondary to muscle injury, and inflammatory-mediated production of ROS and subsequent oxidation of macromolecules after aerobic, concentric, and eccentric training, may be involved (3-6).

Most of the studies examining oxidative stress with acute/chronic exercise were performed using exercises involving a combination of concentric and eccentric contractions; however, activated skeletal muscles are more likely to be injured by lengthening rather than shortening contractions, and this explains the greater muscle damages reported with eccentric exercise $(3,7)$.

Especially in eccentric exercise, the generation of ROS has been attributed to xanthine and NADPH oxidase production, ischemia/reperfusion, prostanoid metabolism, phagocyte respiratory burst, disruption of iron-containing proteins, and excessive calcium accumulation resulting from high-force eccentric exercise, which usually produces muscle injury (8-10).

Several studies have tested the effects of eccentric contractions $(5,7,8)$ and intermittent eccentric chronic exercise (4) on muscle damage, inflammation, mitochondrial enzyme activity, and oxidative stress markers. On the other hand, skeletal muscle injury resulting from downhill running can be prevented by only 5 days of intermittent downhill running at low speed (4), suggesting

Correspondence: L.A. Silva, Laboratório de Fisiologia e Bioquímica do Exercício, Programa de Pós-Graduação em Ciências da Saúde, Universidade do Extremo Sul Catarinense, Av. Universitária, 1105, 88806-000 Criciúma, SC, Brasil. Fax: +55-48-431-2622. E-mail: luciano_acordi@yahoo.com.br 
that an adaptation takes place in response to the initial injury as well as a subsequent recovery from eccentric exercise (6).

However, many questions still remain unanswered regarding the effects of continuous downhill running at moderate speed. These include: a) Does continuous downhill running cause a positive or negative change in the activity of mitochondrial respiratory chain enzymes? b) Does continuous downhill running decrease the oxidative stress, muscle damage, and inflammation induced by eccentric contractions? Thus, the aim of the present study was to determine the effects of moderate continuous downhill running on the activity of mitochondrial respiratory chain enzymes, oxidative stress parameters, muscle damage, and inflammation of skeletal muscle.

\section{Material and Methods}

\section{Animals}

The study protocol was reviewed and approved by the Ethics Committee of Universidade do Extremo Sul Catarinense, Criciúma, SC, Brazil, according to the Guidelines for Animal Care and Experimentation (11). A total of 18 male mice (CF1) aged 3 months and weighing 30-35 g were housed in cages with a maximum of 6 animals per cage and with water and food ad libitum. The animals were kept on a 12 -h light/dark cycle at $23^{\circ} \mathrm{C}$.

\section{Exercise}

The animals were divided into the following groups ( $N=6$ each): untrained (UT), trained eccentric running (TER), and trained running (TR). The exercise-training groups were subjected to running on a motor-driven treadmill by using a progressive exercise-training regimen. All animals were accustomed to treadmill running for 1 week (10 m/min without inclination for $10 \mathrm{~min} /$ day $)$. After a 1-week adaptation period, the trained groups (TER and TR) were submitted to an 8-week training program. The velocity of the treadmill was $13 \mathrm{~m} / \mathrm{min}$ during the first 4 weeks, and $16 \mathrm{~m} / \mathrm{min}$ during the later weeks.

\section{Training}

TER. The TER program was applied at night (6:00 to $8: 00 \mathrm{pm}$ ) and consisted of one session of downhill running ( $16^{\circ}$ decline) for $45 \mathrm{~min} /$ day, 5 days/week for 8 weeks.

$T R$. TR was performed at the same time as TER and consisted of one session of running $\left(0^{\circ}\right)$ for $45 \mathrm{~min} /$ day, 5 days/week for 8 weeks.

\section{Animal sacrifice}

Forty-eight hours after the last training session, the animals were killed by decapitation. Blood was removed by heart puncture, centrifuged at $1500 \mathrm{~g}$ for $10 \mathrm{~min}$ at $4^{\circ} \mathrm{C}$, and serum samples were taken and stored at $2^{\circ} \mathrm{C}$. The quadriceps muscles (red portion type I fiber) were surgically removed, and the samples were immediately stored at $-70^{\circ} \mathrm{C}$ for later analysis. Serum was used for the determination of creatine kinase (CK) activity and the quadriceps muscles (red portion) were used to analyze succinate dehydrogenase (SDH) and myeloperoxidase (MPO) activities, mitochondrial respiratory chain enzyme activities (complexes I and II), and oxidative stress markers.

\section{Biochemical analyses}

Homogenate preparation. Quadriceps muscles were homogenized (Marcone, Brazil; 1:10, w/v) in SETH buffer (250 mM sucrose, 2 mM EDTA, $10 \mathrm{mM}$ Trizma base, $50 \mathrm{IU} / \mathrm{mL}$ heparin, $\mathrm{pH}$ 7.4). The homogenates were centrifuged at $800 \mathrm{~g}$ for $10 \mathrm{~min}$, and the supernatant solutions were maintained at $-70^{\circ} \mathrm{C}$ until the determination of SDH and mitochondrial respiratory chain enzyme activities (complexes I and II). The maximum period between homogenate preparation and enzyme analysis was $<5$ days.

$\mathrm{SDH}$. Phenazine oxidoreductase (soluble SDH) was measured by the decrease in absorbance due to the reduction of 2,6-dichloroindophenol (DCIP) at $600 \mathrm{~nm}$ with $700 \mathrm{~nm}$ as the reference wavelength $(\varepsilon=$ $19.1 \mathrm{mM}^{-1} \cdot \mathrm{cm}^{-1}$ ) in the presence of phenazine methosulfate (PMS). The reaction mixture consisted of $40 \mathrm{mM}$ potassium phosphate, $\mathrm{pH} 7.4,16 \mathrm{mM}$ succinate, and $8 \mathrm{mM}$ DCIP. DCIP was preincubated with $40-80 \mathrm{mg}$ homogenate protein at $30^{\circ} \mathrm{C}$ for $20 \mathrm{~min}$. Subsequently, $4 \mathrm{mM}$ sodium azide, $7 \mathrm{mM}$ rotenone, and $40 \mathrm{mM}$ DCIP were added, and the reaction was initiated by the addition of $1 \mathrm{mM}$ PMS and monitored for $5 \mathrm{~min}$ (12).

Mitochondrial respiratory chain enzyme activities. On the day of the assays, the samples were frozen and defrosted three times in hypotonic assay buffer to fully expose the enzymes to the substrates and to achieve maximal activity. NADH dehydrogenase (complex I) was evaluated by the method described by Cassina and Radi (13) by measuring the rate of NADH-dependent ferricyanide reduction at $420 \mathrm{~nm}$. The activity of succinate: DCIP oxidoreductase (complex II) was determined by the method of Fischer et al. (12). Complex II activity was measured by monitoring the decrease in absorbance due to the reduction of 2,6-DCIP at $600 \mathrm{~nm}$. The activities of the mitochondrial respiratory chain complexes are reported as $\mathrm{nmol} \cdot \mathrm{min}^{-1} \cdot \mathrm{mg}$ protein ${ }^{-1}$ (40-80 $\mathrm{g}$ homogenate protein).

Ferrous oxidation-xylenol orange (xylenol). This method detects hydroperoxides $(\mathrm{ROOHs})$ that are the products of lipoperoxidation (14). The xylenol orange assay is based on the oxidation of ferrous ions to ferric ions by $\mathrm{ROOHs}$ under acidic conditions. Tissues were homogenized $(30 \mathrm{mg} / \mathrm{mL})$, and aliquots $(90 \mu \mathrm{L})$ were transferred to microcentrifuge vials $(1.0 \mathrm{~mL})$. Ten microliters of $10 \mathrm{mM}$ thiamine pyrophosphate in methanol was added to the vials to reduce $\mathrm{ROOHs}$. The vials were then vortexed and incubated at room temperature for $30 \mathrm{~min}$ before the addition of $900 \mu \mathrm{L}$ Fox2 reagent. After mixing, 
the samples were incubated at room temperature for an additional $30 \mathrm{~min}$. The vials were centrifuged at $2400 \mathrm{~g}$ for 10 min with a swing-out rotor (Hettich Rotanta/RP centrifuge, Hettich-Zentrifugen, Germany). Absorbance of the supernatant was measured at $560 \mathrm{~nm}$ using an Ultraspec 2000 spectrophotometer (Pharmacia Biotech, Sweden).

Protein carbonyls (PCs). Oxidative damage to proteins was measured by the determination of carbonyl groups based on the reaction with 2,4-dinitrophenylhydrazine (DNPH) (15). Proteins were precipitated by the addition of $20 \%$ trichloroacetic acid and reacted with DNPH. The samples were then redissolved in $6 \mathrm{M}$ guanidine hydrochloride, and carbonyl contents were determined by measuring the absorbance at $370 \mathrm{~nm}$ with a molar absorption coefficient of $220,000 \mathrm{M}^{-1}$.

Total superoxide dismutase (SOD) and catalase (CAT) activities. In order to determine CAT activity, tissue portions were sonicated in $50 \mathrm{mM}$ phosphate buffer, and the resulting suspension was centrifuged at $3000 \mathrm{~g}$ for $10 \mathrm{~min}$. The supernatant was used for enzyme assay. CAT activity was reported as the rate of decrease in hydrogen peroxide $(10 \mathrm{mM})$ absorbance at $240 \mathrm{~nm}(16)$. SOD activity was determined by measuring the inhibition of adrenaline self-oxidation absorbance at $480 \mathrm{~nm}$ (17).

CK. A specific kit supplied by LABTEST Diagnóstica S.A. (Brazil) was used. Serum CK levels were determined according to manufacturer instructions.

MPO activity in skeletal muscle. Tissues were homogenized $(50 \mathrm{mg} / \mathrm{mL})$ in $0.5 \%$ hexadecyltrimethylammonium bromide and centrifuged at $15,000 \mathrm{~g}$ for $40 \mathrm{~min}$. The suspension was then sonicated three times for $30 \mathrm{~s}$. An aliquot of the supernatant was mixed with a solution of $1.6 \mathrm{mM}$ tetramethylbenzidine and $1 \mathrm{mM} \mathrm{H}_{2} \mathrm{O}_{2}$. The activity was measured spectrophotometrically as a change in absorbance at $650 \mathrm{~nm}$ at $37^{\circ} \mathrm{C}(18)$.

Protein determination. The amount of protein in the samples tested for MPO, SDH, complexes I and II enzyme activities, xylenol, PC, CAT, and SOD activities was determined by the method of Lowry et al. (19) using bovine serum albumin as standard.

\section{Statistical analysis}

Data are reported as mean \pm SE and were analyzed statistically by the two-way analysis of variance (ANOVA) followed by the post hoc Tukey HSD test. The level of significance was set at $95 \%(P<0.05)$. The software used for the analysis of the data was the Statistical Package for the Social Sciences (SPSS) version 16.0 for Windows.

\section{Results}

\section{Enzyme activities of the mitochondrial respiratory chain}

$S D H$. A significant increase in $\mathrm{SDH}$ activity was observed in the TER $\left(8.4 \pm 0.4 \mathrm{nmol} \cdot \mathrm{min}^{-1} \cdot \mathrm{mg}\right.$ protein $\left.^{-1}\right)$ and TR $\left(8.3 \pm 0.3 \mathrm{nmol} \cdot \mathrm{min}^{-1} \cdot \mathrm{mg} \mathrm{protein}^{-1}\right)$ groups compared to the UT group (4.1 \pm $0.5 \mathrm{nmol} \cdot \mathrm{min}^{-1} \cdot \mathrm{mg} \mathrm{protein}^{-1}$ ) (Figure $1 \mathrm{~A}$ ).

Complex I. An increase in complex I activity was observed in the TER $\left(189 \pm 23 \mathrm{nmol} \cdot \mathrm{min}^{-1} \cdot \mathrm{mg}\right.$ protein $\left.{ }^{-1}\right)$ and TR $\left(196 \pm 11 \mathrm{nmol} \cdot \mathrm{min}^{-1} \cdot \mathrm{mg}\right.$ protein $\left.{ }^{-1}\right)$ groups compared to the UT group (84.1 $\pm 6 \mathrm{nmol} \cdot \mathrm{min}^{-1} \cdot \mathrm{mg}$ protein $\left.^{-1}, \mathrm{P}<0.05\right)$ (Figure 1B).

Complex II. An increase in complex II activity was observed in the TER $\left(1.3 \pm 0.07 \mathrm{nmol} \cdot \mathrm{min}^{-1} \cdot \mathrm{mg} \mathrm{protein}^{-1}\right)$ and TR $\left(1.2 \pm 0.1 \mathrm{nmol} \cdot \mathrm{min}^{-1} \cdot \mathrm{mg}\right.$ protein $\left.^{-1}\right)$ groups compared to the UT group $\left(0.7 \pm 0.08 \mathrm{nmol} \cdot \mathrm{min}^{-1} \cdot \mathrm{mg}\right.$ protein $\left.^{-1}, \mathrm{P}<0.05\right)$ (Figure $1 \mathrm{C}$ ).

\section{Oxidative damage}

Xylenol. The level of hydroperoxides in the quadriceps muscles increased in the TER $(32 \pm 2.2 \mathrm{nmol} / \mathrm{mg}$ protein) and decreased in the TR $(12 \pm 1.5 \mathrm{nmol} / \mathrm{mg}$ protein) groups compared to the UT group (23 \pm $1.8 \mathrm{nmol} / \mathrm{mg}$ protein, $\mathrm{P}<0.05$ ) (Figure $2 \mathrm{~A}$ ).

$P C s$. As shown in Figure $2 \mathrm{~B}$, there was an increase in PCs in the quadriceps muscles of the TER group (0.79 \pm $0.05 \mathrm{nmol} / \mathrm{mg}$ protein) and a decrease in the TR group $(0.30 \pm 0.04 \mathrm{nmol} / \mathrm{mg}$ protein) compared to the UT group $(0.49 \pm 0.03 \mathrm{nmol} / \mathrm{mg}$ protein, $\mathrm{P}<0.05)$.

\section{Antioxidant enzyme activity}

$S O D$. Figure $3 \mathrm{~A}$ demonstrates an increase in SOD activity in the quadriceps muscles of the TER (1.6 \pm $0.21 \mathrm{U} / \mathrm{mg}$ protein) and TR $(1.5 \pm 0.16 \mathrm{U} / \mathrm{mg}$ protein, $\mathrm{P}<0.05)$ groups compared to the UT group $(0.89 \pm$ $0.11 \mathrm{U} / \mathrm{mg}$ protein).

CAT. A significant increase in CAT activity was observed in the quadriceps muscles of the TER $(1.2 \pm$ $0.05 \mathrm{U} / \mathrm{mg}$ protein) and TR $(1.1 \pm 0.07 \mathrm{U} / \mathrm{mg}$ protein $)$ groups compared to the UT group $(0.62 \pm 0.09 \mathrm{U} / \mathrm{mg}$ protein) (Figure 3B).

\section{Muscle damage and inflammation}

CK. A significant increase in serum CK activity was observed in the TER group (323 $\pm 19 \mathrm{U} / \mathrm{L})$ compared with the TR $(104 \pm 22 \mathrm{U} / \mathrm{L})$ and UT $(111 \pm 12 \mathrm{U} / \mathrm{L})$ groups (Figure 4A).

MPO activity. MPO activity was significantly elevated in the quadriceps muscles of the TER group $(341 \pm 40$ activity/MPO protein) compared to the TR (192 \pm 21 activity/MPO protein) and UT (188 \pm 20 activity/MPO protein) groups (Figure 4B).

\section{Discussion}

This study presented data demonstrating that TER is not harmful to mitochondrial function, improving the oxidative capacity of muscle (SDH, complexes I and II) similar to TR. However, only TR decreases oxidative 
damage (xylenol and PCs). Antioxidant enzyme activity (SOD and CAT) increased after TER and TR. Furthermore, TER did not decrease muscle damage (CK), inflammation (MPO), or oxidative stress induced by
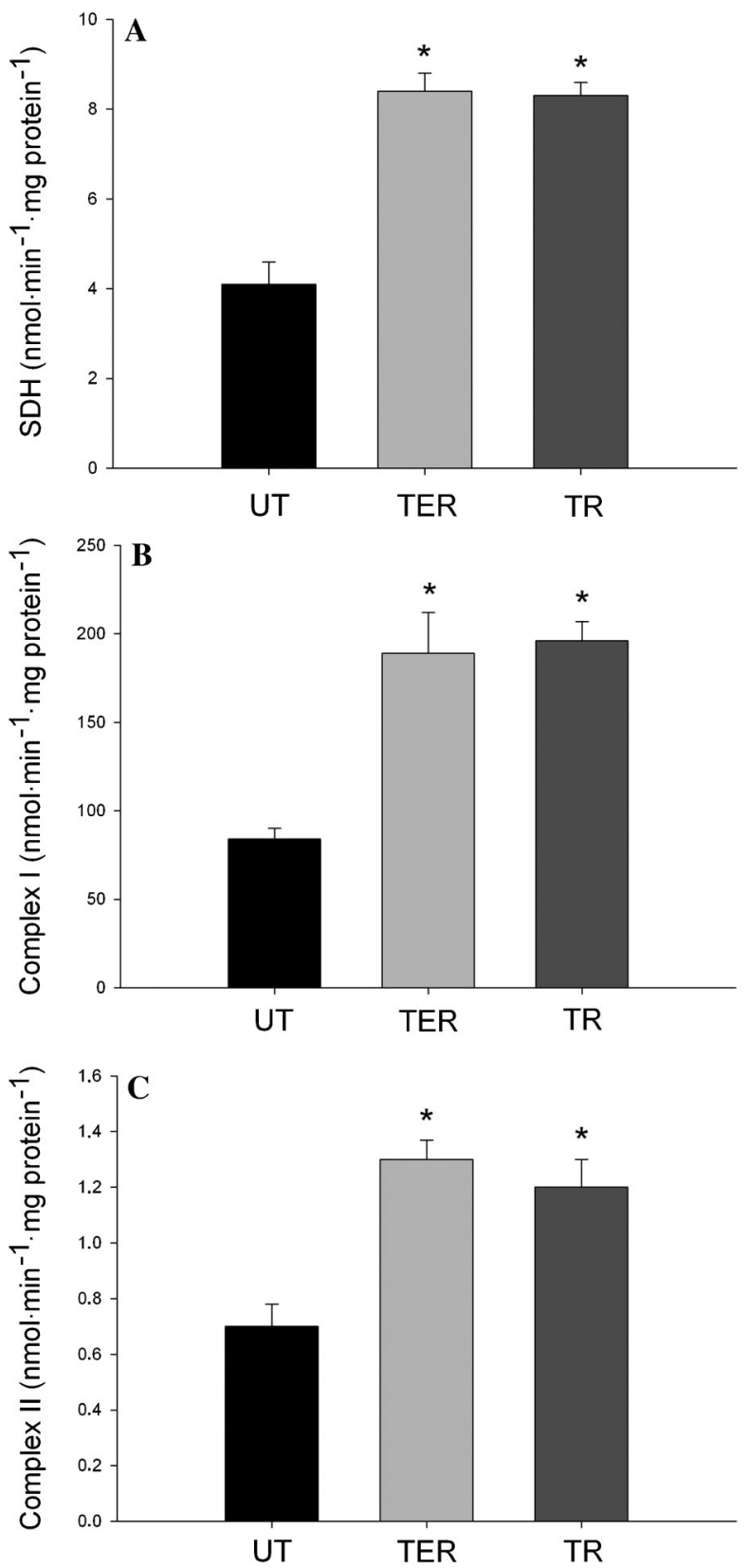

Figure 1. Mitochondrial respiratory chain enzyme activities [succinate dehydrogenase (SDH) $(A)$, complex I $(B)$, and complex II (C)] were determined in skeletal muscle $48 \mathrm{~h}$ after the last session of training. The animals were divided into 3 groups $(\mathrm{N}=$ 6 each): UT $=$ untrained; TER $=$ trained eccentric running (16 ${ }^{\circ}$; $\mathrm{TR}=$ trained running $\left(0^{\circ}\right)$. Data are reported as means $\pm \mathrm{SE}$. ${ }^{*} \mathrm{P}<0.05$ compared to the UT group (Tukey HSD test) eccentric contractions

The metabolic response of the muscles to endurance training has been estimated by measuring the markers of oxidative capacity with an increase in the electron transport chain enzyme activities $(5,20)$. Molnar et al. (3) demonstrated that intermittent eccentric training leads to positive adaptations in the mitochondria. However, we were the first to demonstrate that continuous eccentric training (TER group) similarly increased the activities of SDH and mitochondrial complexes I and II (Figure 1A-C) compared to the TR group. Both types of training involved the same volume and intensity. On the basis of these data, we suggest that eccentric training is not harmful to mitochondrial function.

An important adaptation that accompanies regular endurance training is a decrease in the level of ROS generated in the mitochondria (21). Studies have shown that regular exercise reduces oxidative damage to the
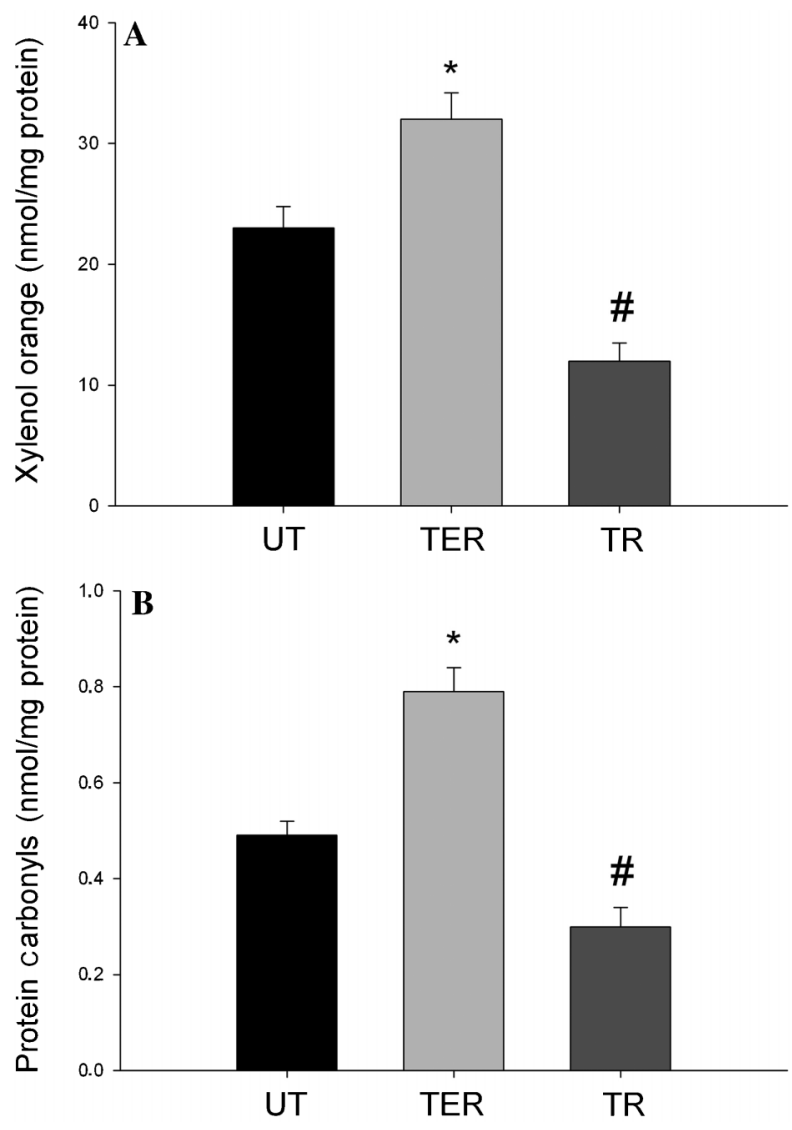

Figure 2. The level of oxidative damage [ferrous oxidationxylenol orange $(A)$ and protein carbonyls $(B)]$ was determined in skeletal muscle (red portion - quadriceps) $48 \mathrm{~h}$ after the last session of training. The animals were divided into 3 groups $(\mathrm{N}=$ 6 each): UT $=$ untrained; TER = trained eccentric running $\left(16^{\circ}\right)$; $\mathrm{TR}=$ trained running $\left(0^{\circ}\right)$. Data are reported as means $\pm \mathrm{SE}$. ${ }^{*} \mathrm{P}<0.05$ compared to the UT group; ${ }^{\#} \mathrm{P}<0.05$ compared to the UT and TER groups (Tukey HSD test). 
brain (22), liver (23), and muscles (8) of rats. Our results demonstrated a decrease in oxidative damage in the TR group and an increase in the TER group (Figure $2 \mathrm{~A}$ and B) compared to the UT group. Several mechanisms can help explain the decrease in the oxidative damage induced by training $(5,24)$. However, this increase in the oxidative damage induced by TER is consistent with that reported by Molnar et al. (3) with regard to chronic eccentric exercise-enhanced oxidative stress. It is possible that eccentric contractions performed daily ( 5 days a week), with no time for sufficient muscle recovery, induce oxidative stress.

Various studies have reported increased antioxidant defenses under chronic conditions $(1,25)$. Our results demonstrated increased activity of two enzymes (SOD Figure 3A, and CAT - Figure 3B) similarly induced by TER and TE. Both kinds of training involved the same volume (45 min/day) and intensity $(16 \mathrm{~m} / \mathrm{min})$. The eccentric
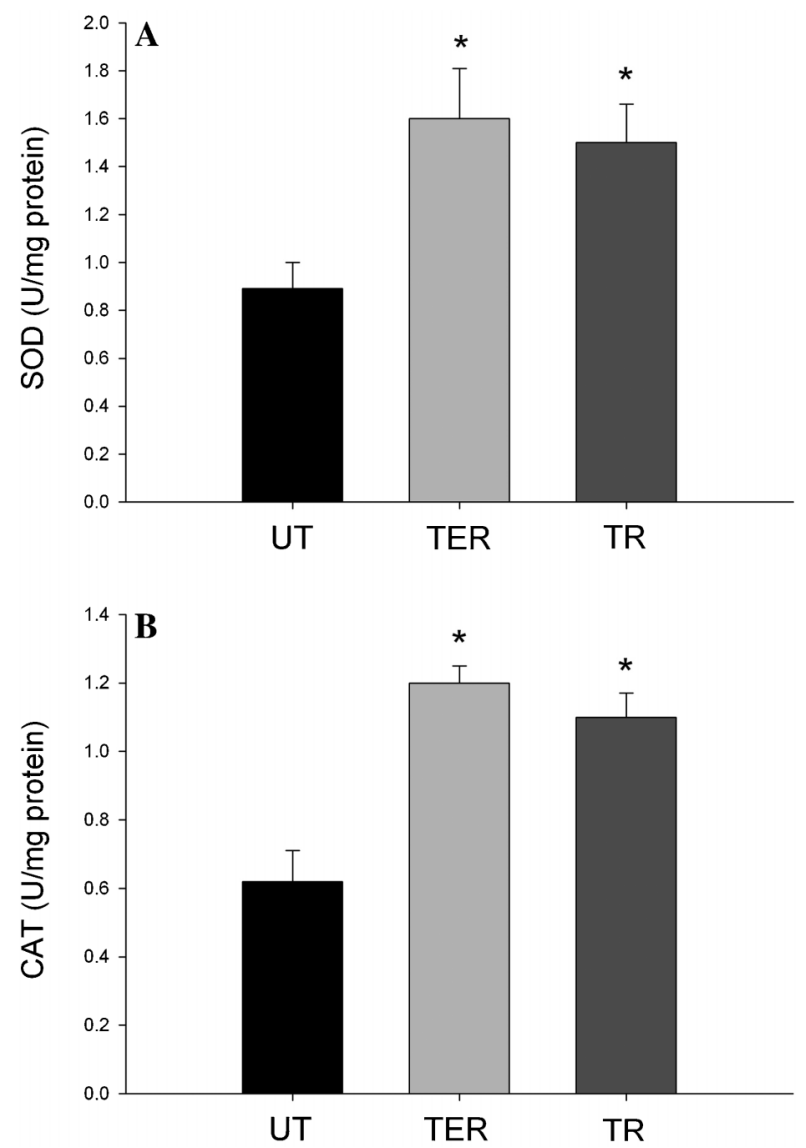

Figure 3. Antioxidant enzyme levels $[A$, superoxide dismutase (SOD) and $B$, catalase (CAT)] were determined in skeletal muscle (red portion - quadriceps) $48 \mathrm{~h}$ after the last training session. The animals were divided into 3 groups $(\mathrm{N}=6$ each): $\mathrm{UT}=$ untrained; TER $=$ trained eccentric running $\left(16^{\circ}\right)$; TR $=$ trained running $\left(0^{\circ}\right)$. Data are reported as means $\pm \mathrm{SE}$. ${ }^{*} \mathrm{P}<$ 0.05 compared to the UT group (Tukey HSD test). contraction is not harmful to the function of enzymes. These results showed that chronic contractile activity also appears to influence the ability of the muscles to detoxify superoxide and hydrogen peroxide with an increase in skeletal SOD (26) and CAT (25). The increase in the enzymes can explain the reduction of oxidative damage in the TR group. However, in the TER group, increased SOD and CAT activities were not sufficient to protect from oxidative stress.

Some studies have reported that repeated eccentric exercise-induced adaptations decrease muscle damage and inflammation $(6,27)$. Neural, mechanical, and cellular mechanisms are speculated to be causally related to the development of a repeated bout effect $(28,29)$. However, this was not confirmed in the present study. We demonstrated that eccentric training caused muscle damage (increased serum CK - Figure 4A), which led to neutrophil invasion (increased muscle MPO - Figure 4B). This can
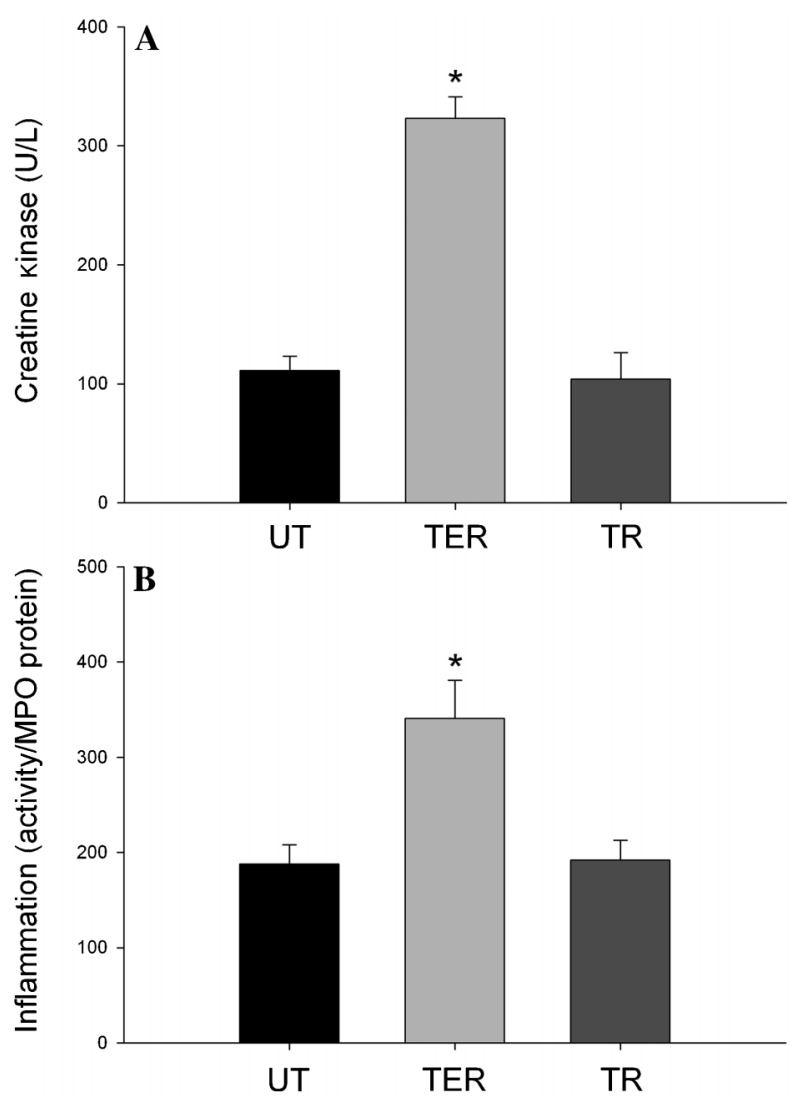

Figure 4. Muscle damage ( $A$, creatine kinase) and inflammation $(B$, myeloperoxidase, MPO) levels were determined in skeletal muscle (red portion - quadriceps) $48 \mathrm{~h}$ after the last training session. The animals were divided into 3 groups $(\mathrm{N}=6$ each): $\mathrm{UT}=$ untrained; TER $=$ trained eccentric running $\left(16^{\circ}\right)$; $\mathrm{TR}=$ trained running $\left(0^{\circ}\right)$. Data are reported as means $\pm \mathrm{SE}$. ${ }^{*} \mathrm{P}<$ 0.05 compared to the UT group (Tukey HSD test). 
be explained by the fact that eccentric contractions activate inflammatory cells to accumulate in skeletal muscle, causing an increase in ROS production and in transcription factors such as nuclear factor-kappaB activation, causing muscle damage and inflammation $(8,26,30,31)$.

Greater MPO content increases hydroperoxide production (xylenol - Figure 2A) and causes protein oxidation (carbonyls - Figure 2B). Eccentric exercise induces pathologic changes such as fiber necrosis and inflammatory cell infiltration that become apparent a few days after exercise (32). If this initial triggering damage during eccentric contractions were strong enough to induce a sustained elevation of intracellular $\mathrm{Ca}^{2+}$ concentration after exercise, then various proteases and phospholipases would be eventually activated $(32,33)$, causing necrosis. Damaged connective tissue and necrotic fibers would then induce and activate the inflammatory cell infiltration that accompanies ROS production (9,33-35) and increases damaging oxidants $(2,9,10)$.

Therefore, eccentric training has a dual effect on the muscle: without adequate recovery, the muscle is damaged in eccentric training, while with recovery, eccentric training protects the muscle from this damage. Detailed mechanisms underlying this dual effect have not yet been fully studied experimentally $(36,37)$. Vissing et al.

\section{References}

1. Pinho RA, Andrades ME, Oliveira MR, Pirola AC, Zago MS, Silveira PC, et al. Imbalance in SOD/CAT activities in rat skeletal muscles submitted to treadmill training exercise. Cell Biol Int 2006; 30: 848-853, doi: 10.1016/j.cellbi.2006. 03.011.

2. Bloomer RJ, Goldfarb AH, Wideman L, McKenzie MJ, Consitt LA. Effects of acute aerobic and anaerobic exercise on blood markers of oxidative stress. J Strength Cond Res 2005; 19: 276-285.

3. Molnar AM, Servais S, Guichardant M, Lagarde M, Macedo DV, Pereira-Da-Silva L, et al. Mitochondrial $\mathrm{H}_{2} \mathrm{O}_{2}$ production is reduced with acute and chronic eccentric exercise in rat skeletal muscle. Antioxid Redox Signal 2006; 8: 548-558, doi: 10.1089/ars.2006.8.548.

4. Schwane JA, Armstrong RB. Effect of training on skeletal muscle injury from downhill running in rats. J Appl Physiol 1983; 55: 969-975

5. Silva LA, Pinho CA, Scarabelot KS, Fraga DB, Volpato AM, Boeck CR, et al. Physical exercise increases mitochondrial function and reduces oxidative damage in skeletal muscle. Eur J Appl Physiol 2009; 105: 861-867, doi: 10.1007/ s00421-008-0971-8.

6. Stupka N, Tarnopolsky MA, Yardley NJ, Phillips SM. Cellular adaptation to repeated eccentric exercise-induced muscle damage. J Appl Physiol 2001; 91: 1669-1678.

7. Duan C, Delp MD, Hayes DA, Delp PD, Armstrong RB. Rat skeletal muscle mitochondrial $\left[\mathrm{Ca}^{2+}\right]$ and injury from downhill walking. J Appl Physiol 1990; 68: 1241-1251.

8. Silva LA, Silveira PC, Pinho CA, Tuon T, Dal PF, Pinho RA.
(38) showed that this heat shock protein response to eccentric exercise was concurrently attenuated with attenuation of muscle damage when eccentric exercise was repeated 8 weeks later. In the present study, the time of recovery of $24 \mathrm{~h}$ between training sessions was insufficient to promote positive adaptations, with consequent muscle damage, inflammation, and oxidative stress. However, the discrepancies in the results may result from different training models (e.g., treadmill running, bicycle, strength, and swimming); different training volumes $(15,30,45$, and $60 \mathrm{~min})$, intensities (low, moderate, and high), and frequencies (2, 3, and 5) per week, and different species (e.g., rats, mice, and humans).

In addition, the effect of TER may occur on different pathways without directly involving the mitochondrial metabolism. Muscle damage can be induced by mechanical factors during eccentric contractions (39) such as production of free radicals by cytosolic sources, for example, activation of xanthine oxidase, catecholamines, and prostaglandins $(2,40)$, and activation of inflammation or transcription factors (31).

The results of this study suggest that eccentric running training improves mitochondrial function but does not reduce oxidative damage, muscle damage, or the inflammation induced by eccentric contractions.
$\mathrm{N}$-acetylcysteine supplementation and oxidative damage and inflammatory response after eccentric exercise. Int $J$ Sport Nutr Exerc Metab 2008; 18: 379-388.

9. Childs A, Jacobs C, Kaminski T, Halliwell B, Leeuwenburgh C. Supplementation with vitamin $\mathrm{C}$ and $\mathrm{N}$-acetyl-cysteine increases oxidative stress in humans after an acute muscle injury induced by eccentric exercise. Free Radic Biol Med 2001; 31: 745-753, doi: 10.1016/S0891-5849(01)00640-2.

10. Silva LA, Silveira PC, Ronsani MM, Souza PS, Scheffer D, Vieira LC, et al. Taurine supplementation decreases oxidative stress in skeletal muscle after eccentric exercise. Cell Biochem Funct 2011; 29: 43-49, doi: 10.1002/cbf.1716.

11. Olert ED, Cross BM, Mcwillians AA. Guide to care and use of experimental animals. 2nd edn. OttawaCanadian Council on Animal; 2003.

12. Fischer JC, Ruitenbeek W, Berden JA, Trijbels JM, Veerkamp JH, Stadhouders AM, et al. Differential investigation of the capacity of succinate oxidation in human skeletal muscle. Clin Chim Acta 1985; 153: 23-36, doi: 10.1016/ 0009-8981(85)90135-4.

13. Cassina A, Radi R. Differential inhibitory action of nitric oxide and peroxynitrite on mitochondrial electron transport. Arch Biochem Biophys 1996; 328: 309-316, doi: 10.1006/ abbi.1996.0178.

14. Jiang ZY, Woollard AC, Wolff SP. Lipid hydroperoxide measurement by oxidation of $\mathrm{Fe}^{2+}$ in the presence of xylenol orange. Comparison with the TBA assay and an iodometric method. Lipids 1991; 26: 853-856, doi: 10.1007/ BF02536169. 
15. Levine RL, Garland D, Oliver CN, Amici A, Climent I, Lenz $A G$, et al. Determination of carbonyl content in oxidatively modified proteins. Methods Enzymol 1990; 186: 464-478, doi: 10.1016/0076-6879(90)86141-H.

16. Aebi H. Catalase in vitro. Methods Enzymol 1984; 105: $121-$ 126, doi: 10.1016/S0076-6879(84)05016-3.

17. Bannister JV, Calabrese L. Assays for superoxide dismutase. Methods Biochem Anal 1987; 32: 279-312, doi: 10.1002/9780470110539.ch5.

18. De Young LM, Kheifets JB, Ballaron SJ, Young JM. Edema and cell infiltration in the phorbol ester-treated mouse ear are temporally separate and can be differentially modulated by pharmacologic agents. Agents Actions 1989; 26: 335341, doi: 10.1007/BF01967298.

19. Lowry OH, Rosebough NG, Farr AL, Randall RJ. Protein measurement with the Folin phenol reagent. J Biol Chem 1951; 193: 265-275.

20. Fernstrom M, Tonkonogi M, Sahlin K. Effects of acute and chronic endurance exercise on mitochondrial uncoupling in human skeletal muscle. J Physiol 2004; 554: 755-763, doi: 10.1113/jphysiol.2003.055202.

21. Venditti $\mathrm{P}$, Masullo $\mathrm{P}, \mathrm{Di}$ Meo $\mathrm{S}$. Effect of training on $\mathrm{H}\left({ }_{2}\right) \mathrm{O}_{2}$ ) release by mitochondria from rat skeletal muscle. Arch Biochem Biophys 1999; 372: 315-320, doi: 10.1006/ abbi.1999.1494.

22. Radak Z, Kaneko T, Tahara S, Nakamoto H, Pucsok J, Sasvari $M$, et al. Regular exercise improves cognitive function and decreases oxidative damage in rat brain. Neurochem Int 2001; 38: 17-23, doi: 10.1016/S01970186(00)00063-2.

23. Radak Z, Chung HY, Naito H, Takahashi R, Jung KJ, Kim $\mathrm{HJ}$, et al. Age-associated increase in oxidative stress and nuclear factor kappaB activation are attenuated in rat liver by regular exercise. FASEB J 2004; 18: 749-750.

24. Ji LL, Gomez-Cabrera MC, Vina J. Exercise and hormesis: activation of cellular antioxidant signaling pathway. Ann N Y Acad Sci 2006; 1067: 425-435, doi: 10.1196/annals.1354. 061.

25. da Silva LA, Pinho CA, Rocha LG, Tuon T, Silveira PC, Pinho RA. Effect of different models of physical exercise on oxidative stress markers in mouse liver. Appl Physiol Nutr Metab 2009; 34: 60-65, doi: 10.1139/H08-132.

26. McArdle A, Pattwell D, Vasilaki A, Griffiths RD, Jackson MJ. Contractile activity-induced oxidative stress: cellular origin and adaptive responses. Am J Physiol Cell Physiol 2001; 280: C621-C627.

27. Chen TC, Hsieh SS. Effects of a 7-day eccentric training period on muscle damage and inflammation. Med Sci Sports Exerc 2001; 33: 1732-1738, doi: 10.1097/ 00005768-200110000-00018.

28. Nosaka K, Newton M. Concentric or eccentric training effect on eccentric exercise-induced muscle damage. Med Sci
Sports Exerc 2002; 34: 63-69, doi: 10.1097/00005768200205001-01034.

29. McHugh MP. Recent advances in the understanding of the repeated bout effect: the protective effect against muscle damage from a single bout of eccentric exercise. Scand $J$ Med Sci Sports 2003; 13: 88-97, doi: 10.1034/j.16000838.2003.02477.x.

30. Hollander J, Fiebig R, Gore M, Ookawara T, Ohno H, Ji LL. Superoxide dismutase gene expression is activated by a single bout of exercise in rat skeletal muscle. Pflugers Arch 2001; 442: 426-434, doi: 10.1007/s004240100539.

31. Jimenez-Jimenez R, Cuevas MJ, Almar M, Lima E, GarciaLopez D, De Paz JA, et al. Eccentric training impairs NF-kappaB activation and over-expression of inflammationrelated genes induced by acute eccentric exercise in the elderly. Mech Ageing Dev 2008; 129: 313-321, doi: 10.1016/ j.mad.2008.02.007.

32. Armstrong RB, Ogilvie RW, Schwane JA. Eccentric exercise-induced injury to rat skeletal muscle. J Appl Physiol 1983; 54: 80-93.

33. Toumi H, Best TM. The inflammatory response: friend or enemy for muscle injury? Br J Sports Med 2003; 37: 284286, doi: 10.1136/bjsm.37.4.284.

34. Best TM, Fiebig R, Corr DT, Brickson S, Ji L. Free radical activity, antioxidant enzyme, and glutathione changes with muscle stretch injury in rabbits. J Appl Physiol 1999; 87: 7482.

35. Lynn R, Talbot JA, Morgan DL. Differences in rat skeletal muscles after incline and decline running. J Appl Physiol 1998; 85: 98-104.

36. Maruhashi Y, Kitaoka K, Yoshiki Y, Nakamura R, Okano A, Nakamura $\mathrm{K}$, et al. ROS scavenging activity and muscle damage prevention in eccentric exercise in rats. J Physiol Sci 2007; 57: 211-216, doi: 10.2170/physiolsci.RP013006.

37. Close GL, Ashton T, Cable T, Doran D, MacLaren DP. Eccentric exercise, isokinetic muscle torque and delayed onset muscle soreness: the role of reactive oxygen species. Eur J Appl Physiol 2004; 91: 615-621, doi: 10.1007/s00421003-1012-2.

38. Vissing K, Bayer ML, Overgaard K, Schjerling $\mathrm{P}$, Raastad $\mathrm{T}$. Heat shock protein translocation and expression response is attenuated in response to repeated eccentric exercise. Acta Physiol 2009; 196: 283-293, doi: 10.1111/j.17481716.2008.01940.x.

39. Hody S, Rogister B, Leprince $\mathrm{P}$, Wang F, Croisier JL. Muscle fatigue experienced during maximal eccentric exercise is predictive of the plasma creatine kinase (CK) response. Scand J Med Sci Sports 2011; 1-7.

40. Fisher-Wellman K, Bloomer RJ. Acute exercise and oxidative stress: a 30 year history. Dyn Med 2009; 8: 1, doi: 10.1186/1476-5918-8-1. 